\title{
Evaluation of Ylang Ylang essential oil on alcohol induced hepatotoxicity in rats
}

\author{
Siddarth Sunil Tubachi ${ }^{1}$ - V. P. Rasal ${ }^{1}$ - Sanjay R. Ugare ${ }^{1} \cdot$ Nayeem A. Khatib $^{1} \cdot$ Prachi Sanjeev Ojha $^{1} \cdot$ Vishal S. Patil $^{2}$
}

Received: 13 August 2021 / Accepted: 8 January 2022

(c) The Author(s) 2022

\begin{abstract}
The present study is aimed to evaluate the effect of ylang ylang essential oil in alcohol induced hepatotoxicity in rats. Alcohol was used as an inducing agent and Silymarin as a standard molecule. Body weight was measured at a 3 days interval till the twenty first day and at the end of the study, serum AST, ALT, TP, TC, TG, and TB biomarkers were estimated. Further, the liver tissue was evaluated for antioxidant enzymes namely CAT, LPO, SOD and GSH level. Liver weight and histopathology was accessed at the end. Phytocompounds were shortlisted from literature and curated databases. Probable targets of each compound were identified using the SwissTargetPrediction web server. Probable mechanisms of phytocompounds against Alcohol induced hepatotoxicity were analyzed by the STRING and KEGG pathway database. The network between compounds, targets, and pathways was generated via Cytoscape ver. 3.6.1. Docking was performed by AutoDock vina using PyRx0.8v. YYEO group showed increased BW compared to alcohol group and also reversed the increased serum AST, ALT, TP, TC, TG, and TB biomarkers and also increased the level of antioxidant enzymes compared to alcohol induced group. YYEO $400 \mathrm{mg} / \mathrm{kg}$ exhibited normal liver weight and histology compared to alcohol. Enrichment and network analysis identified YYEO 63 compounds as beneficial modulators of protein molecules associated with hepatotoxicity via modulating Toll-like receptor, Adipocytokine, TNF, Sphingolipid, FoxO, AMPK, Relaxin, MAPK, NF-kappa B, HIF-1, Fc epsilon RI, IL-17, VEGF, T cell receptor, NOD-like receptor, mTOR, PI3K- Akt signaling pathway, etc. Canangaterpene 1 was identified as a potent inhibitor of aldose reductase.
\end{abstract}

Sanjay R. Ugare

sanjayugare@gmail.com

1 Department of Pharmacology, KLE College of Pharmacy, KLE Academy of Higher Education and Research, Belagavi, Karnataka 590010, India

2 ICMR-National Institute of Traditional Medicine, Belagavi, Karnataka 590010, India 


\section{Graphical abstract}

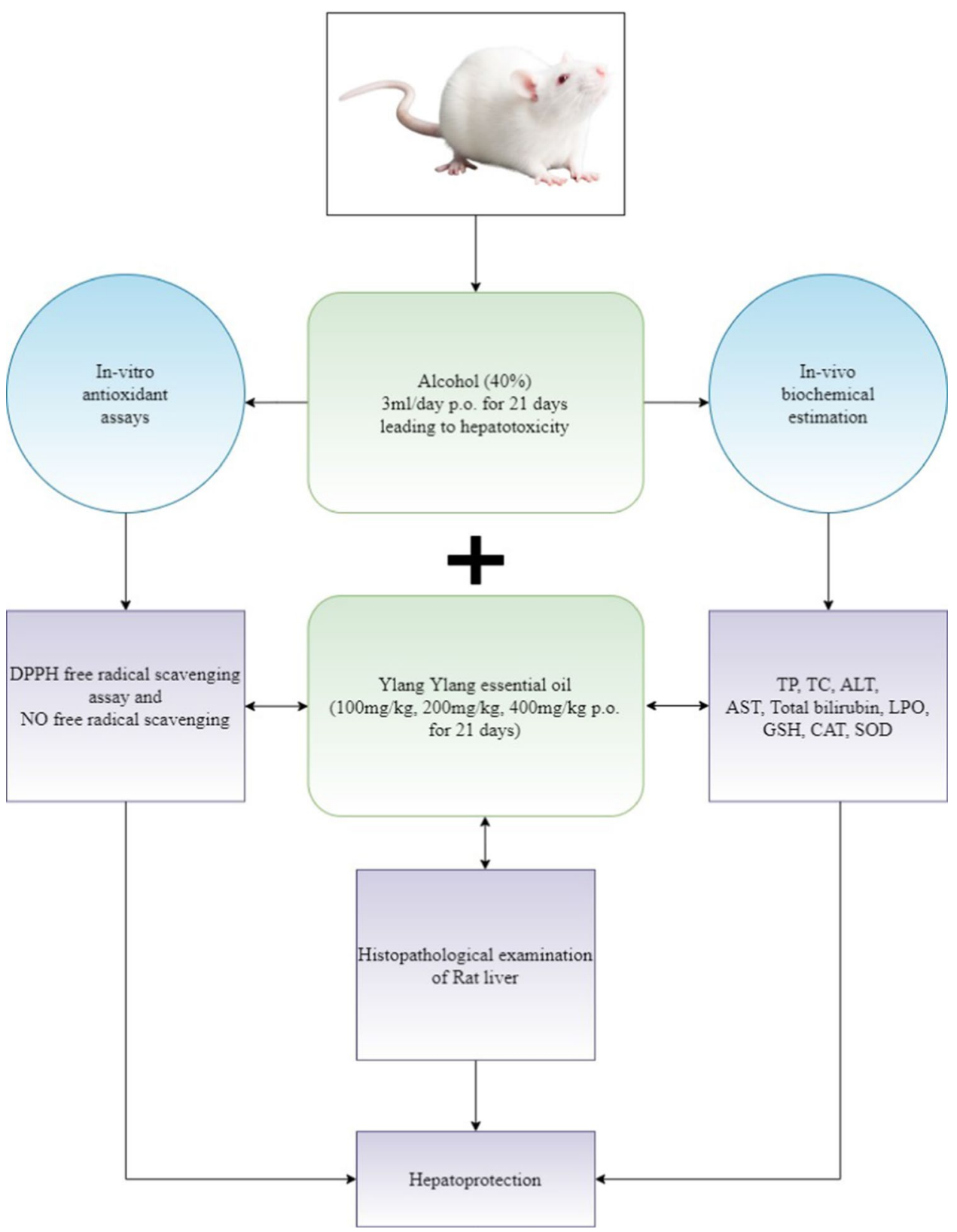

Keywords Hepatotoxicity $\cdot$ Alcohol $\cdot$ Ylang Ylang essential oil $\cdot$ In silico $\cdot$ In vivo $\cdot$ Phytocompounds

\section{Introduction}

The liver is the biggest glandular organ in the body and has maximum activities than other organs in the body. The Liver has a pivotal role in human metabolism and it produces so many actions related to haematology parameters, biochemical parameters, and enzyme-related activities (Sharma et al. 2009). As it is a major functional organ, injury or infection to this organ causes a lot of alterations in the human body.
Hepatic injury happens because of contagions, certain medications, natural and social factors, for example, liquor abuse or alcoholism, drug abuse, etc. (Ali et al. 2004).

One of the major problems associated with hepatic injury/damage is the continued consumption of alcohol by the locals as well as professionals. Alcohol misuse and reliance are turning out to be an undeniably major issue around the world because of its temperament as quite possibly the most generally psychoactive substance. Regular 
and exorbitant liquor utilization leads to around a 2.5 million deaths/year. Alcohol instigated liver injury is a leading main danger issue for the advancement of multiple liver sicknesses. Massive changes occur in tissue defense capacity after usage of liquor, along with modified reticuloendothelial paintings just as altered immune, platelet capacities, granulocyte, lymphocyte (McCuskey et al. 1991).

The utilization of herbs constituents for the management of liver illnesses has a long past and therapeutic herbs and their moieties are as yet utilized everywhere in the world in one form or the other for this reason. Numerous medicinal plants and their derivatives were used as hepato- protectants. The traditional plants available as hepatoprotective are Acacia catechu, Zingiber officinale, Podophyllum hexandrum, Garcinia indica, Asparagus racemosus, and many more (Amit et al. 2014). Also, numerous essential oils played a crucial role in the regulation of hepatotoxicity due to their high content of steroidal compounds.

Among the essential oils obtained from the different parts of plants, Ylang Ylang essential oil (YYEO) separated from the blossoms of Cananga odorata is prestigious for its scent and used in different makeup, massage oils, creams, fragrances, etc. It is extracted by water/water and steam distillation. Customarily YYEO is utilized in treating rheumatism, asthma, antiseptic, gout, stomach ailments, malaria, depression. The essential oil is specifically believed to be antimicrobial, antibiofilm, antiinflammatory, anti-vector, insect repellent, anti-diabetic, and anti-fertility and anti- melanogenesis, antioxidants, etc (Burdock et al. 2008). YYEO consisting of 161 bioactive constituents (reported) or more out of which eugenol, linalool, linalyl acetate, geranyl acetate, germacrene-d, beta- caryophyllene, farnesene, methyl benzoate, geraniol, and quercetin are said to be useful in hepatoprotection. However, no such scientific data are available on in silico and in vivo based hepatoprotective actions by YYEO to validate folkfore claims.

In the field of drug discovery, currently available system biology data in combination with computational or chemoinformatics approaches are being continuously applied to elucidate the molecular mechanisms of herbs/traditional medicines or polyherbal formulation. These methods help researchers to understand the complex relations between the regulation of pathways and protein molecules by phytocompounds.

Thus, based on earlier study reports as mentioned above, the present study is directed to examine the liver protection potency of YYEO by in silico tools (target identification, enrichment analysis, system pharmacology by network analysis, docking, and druggability studies), and by in vivo studies in rodents.

\section{Materials and methods}

\section{Materials used in the current study}

\section{Drugs, chemicals, reagents and diagnostic kits}

Silymarin Tablets Silybon-140, Alcohol, Sodium, DTNB (Ellman's reagent), Potassium dihydrogen phosphate, DPPH, Aspartate aminotransferase kit (AST kit), Alanine transaminase kit (ALT kit), Total protein kit, Bilirubin kit, Total cholesterol Kit (TC kit), etc. were used during the study.

\section{Instruments utilized}

Micropipettes (Finepipette, Thermo Labsystems), cuvettes (0.5 and $3 \mathrm{ml})$, microplate reader (BioRad, model550), autoanalyzer, microcentrifuge (Remi, R \& C), incubator, Teflon homogeniser, rotary vacuum evaporator (JSGW) and many more.

\section{Dose selection for Ylang Ylang essential oil (YYEO)}

YYEO was procured from the certified vendor. As reported in the earlier acute-toxicity studies showed no mortality amongst the treated animals at a dose of $2000 \mathrm{mg} / \mathrm{kg}$ (14 days). Depending onearlier studies, YYEO therapeutic dose was identified to be safe at 100,200 , and $400 \mathrm{mg} / \mathrm{kg}$ BW. Thus $1 / 5$ th, $1 / 10$ th, $1 / 20$ th of the $\mathrm{LD}_{50} 2000 \mathrm{mg} / \mathrm{kg}$ as mentioned above were administered orally for the proposed experiment (Mohan et al. 2002).

\section{In-vitro antioxidant activity}

The DPPH free radical scavenging assay of Ylang Ylang essential oil was performed as explained by Baba et al. (2014). Similarly, the nitrous oxide free radical scavenging assay was carried out as illustrated by Boora et al. (2014). Ascorbic acid was used as a standard. Suitable controls were taken for standard and test compounds and $\mathrm{IC}_{50}$ value was calculated.

\section{Animals}

Male wistar rats weighing 180-220 g were used for the experiment. All the animals were housed in a hygienic and translucent polypropylenecage and randomized into six groups $(N=6$ and $n=6) N=$ Number of groups and $n=$ Number of animals in each group. All the animals were kept under 12/12 $\mathrm{h}$ natural light-dark cycle $\left[27^{\circ} \mathrm{C}\right.$ temp. and $\left.45-55 \% \mathrm{RH}\right]$. The overall research procedure was revised and approved by the 
IAEC, KLE College of Pharmacy, Belagavi. Resolution NoKLECOP/CPCSEA- Reg. No. 221/Po/Re/S/2000/CPCSEA, Res. No. 29-03/09/2020.

\section{Experimental study design}

Group I received normal food and water. Group-II (negative control) received Alcohol (40\%) $3 \mathrm{ml} /$ day orally q.d. up to 21 days. Group III (Positive control) received Silymarin $50 \mathrm{mg} / \mathrm{kg}$ orally and alcohol $3 \mathrm{ml} /$ day p.o. q.d. up to 21 days. Group IV, V and VI (Disease induced) received alcohol (40\%) $3 \mathrm{ml} /$ day p.o. and Ylang Ylang essential oil 100,200 , and $400 \mathrm{mg} / \mathrm{kg}$ body weight p.o. once daily for 21 days respectively. The grouping of animals is illustrated in Table 1. At the end of the study blood was withdrawn via "retro-orbital plexus puncture" and was subjected for the biochemical estimation viz., TP, TC, AST, and ALT; whereas hepatic tissue homogenate was utilized for the evaluation of antioxidant biomarkers viz., LPO, SOD, Catalase, and GSH.

\section{In-vivo biochemical estimations}

At the end of the study, blood was collected from retroorbital plexus. The collected blood was centrifuged at $3000 \mathrm{rpm}$ for $10 \mathrm{~min}$ to separate serum for the estimation of liver parameters such as AST/SGPT, ALT/SGOT, TotalProtein, Total Cholesterol and Total Bilirubin. All these parameters were measured by the YUCCA Kit Standard Procedures.

\section{In-vivo antioxidant activity}

\section{Determination of LPO}

Ohkawa et al. (1979) method was used to estimate the level of MDA in the liver tissue. To $0.2 \mathrm{ml}$ of tissue homogenate $0.2 \mathrm{ml}$ of SLS ( $8.1 \% \mathrm{w} / \mathrm{v})$ was added followed by $1.5 \mathrm{ml}$ of $20 \% \mathrm{CH}_{3} \mathrm{COOH}$ and $1.5 \mathrm{ml}$ TBA $(0.8 \%)$. The above mixture was for $1 \mathrm{~min}$ and diluted up to $4 \mathrm{ml}$ using DM water. Further, it was boiled at $90{ }^{\circ} \mathrm{C}$ for $1 \mathrm{~h}$ using the water bath. The whole mixture was cooled and $1 \mathrm{~mL}$ of $\mathrm{DM}$ water was added followed by $5 \mathrm{~mL}$ [n-butanol: Pyridine, 15:1 v/v) mixture and for $10 \mathrm{~min}$ the solution is centrifuged [rpm: 4000].
The Abs of the organic layer was noted at $532 \mathrm{~nm}$. The cerebrum malondialdehyde (MDA) $\mathrm{mg}^{-1}$ of protein level was estimated and expressed in nanomoles using the formula,

$\mathrm{MDA}=\mathrm{nmoles}$ of $\mathrm{MDA} / \mathrm{mg}$ of protein in the liver is

Concentration $=\mathrm{A} \times(\mathrm{V} / \mathrm{E}) \times \mathrm{P}$

where $\mathrm{A}=\mathrm{Abs}, \mathrm{V}=$ Mixture volume, $\mathrm{E}=1.56 \times 10^{5} \mathrm{~m} / \mathrm{cm}$ extinction coefficient, $\mathrm{P}=\mathrm{mg}$ of protein per $\mathrm{g}$ of tissue.

Data represented in "nM of MDA/mg of protein".

\section{Determination of reduced GSH}

Ellman (1959) method was utilized to estimate liver tissue reduced GSH level. To $0.25 \mathrm{ml}$ of tissue homogenate was added $2.5 \mathrm{ml}$ sodium phosphate buffer followed by $50 \mu \mathrm{l}$ DTNB [pH 7.0]. The above mixture was vortexed and incubated at $25-27^{\circ} \mathrm{C}$ for $2 \mathrm{~min}$. Within $15 \mathrm{~min}$, at $412 \mathrm{~nm}$, read the mixture Abs and expressed GSH level in " $\mu$ moles/mg of tissue".

$\mathrm{C} 0=\mathrm{A} \times \mathrm{D}$

$€$

where $\mathrm{C} 0$ is the original concentration, $\mathrm{A}$ is Absorbance, $€$ is $13,600 / \mathrm{M} / \mathrm{cm}$, D is the "dilution factor".

\section{Determination of catalase}

$50 \mu \mathrm{l}$ of tissue homogenate was mixed with $1.95 \mathrm{ml}$ of PBS $7.0 \mathrm{pH}$ and $1 \mathrm{ml}$ of $0.7 \mathrm{mM} \mathrm{H}_{2} \mathrm{O}_{2}$ solution. Then the absorbance was at $240 \mathrm{~nm}$ (Claiborne et al. 1985).

\section{Determination of SOD}

The capacity of SOD to antagonize the auto-oxidation of epinephrine to adrenochrome in the presence of alkaline $\mathrm{pH}$. To the $25 \mu \mathrm{l}$ of homogenate sample, $0.1 \mathrm{mM}$ of epinephrine was added in carbonate buffer ( $\mathrm{pH}$ 10.2). At $295 \mathrm{~nm}$, the adrenochrome formation in the above mixture was measured using the ELISA plate reader. Further, the CAT and SOD levels were determined from the total protein value and expressed in U/mg of protein (Sun et al. 1978).
Table 1 In vivo study plan, $\mathrm{N}=6$ and $\mathrm{n}=6$

\begin{tabular}{ll}
\hline Animal groups $(\mathrm{N}=6)$ & Treatment \\
\hline Group I (Normal group) & Receives normal food and water \\
Group II (Negative control group) & Alcohol $(40 \%) 3 \mathrm{ml} /$ day for 21 days \\
Group III (Positive control group) & Silymarin $50 \mathrm{mg} / \mathrm{kg}+$ Alcohol $3 \mathrm{ml} /$ day p.o for 21 days \\
Group IV & YYEO $(100 \mathrm{mg} / \mathrm{kg} \mathrm{p.o.})+$ Alcohol $3 \mathrm{ml} /$ day p.o for 21 days \\
Group V & YYEO $(200 \mathrm{mg} / \mathrm{kg} \mathrm{p.o.})+$ Alcohol $3 \mathrm{ml} /$ day p.o for 21 days \\
Group VI & YYEO $(400 \mathrm{mg} / \mathrm{kg} \mathrm{p.o.})+$ Alcohol $3 \mathrm{ml} /$ day p.o for 21 days \\
\hline
\end{tabular}




\section{Histological preparations}

The liver tissues from all the groups were added to $10 \%$ formalin solution and these tissues were processed and implanted in paraffin wax. Sections were cut into $6 \mu \mathrm{m}$ thickness and added with haemotoxylin and eosin dye for low power histopathological examination at $40 \times$ magnification.

\section{In silico studies}

1. Retrieval of bioactives from $Y Y E O$ and collection of their information

The reported bioactive from the $Y Y E O$ were retrieved from the published literature and phytochemical databases. The chemical properties of each bioactive phytocompounds were assessed from the PubChem database viz., Canonical smiles, MW, MF, NHBA, NHBD, and $\log$ P values. The Druggability of each bioactive molecule was predicted by the molsoft online server.

2. Target identification

(a) Targets related to Alcohol

A peer review of the literature was done to identify the specific protein molecules regulated by Alcohol in rodents and cell lines. Based on the literature, a datasheet was built for Alcohol regulated genes that are associated with hepatotoxicity.

(b) Targets related to phytocompounds

Canonical smiles of each compound are quired into SwissTargetPrediction (http://www.swisstargetprediction.ch/) server to predict the probable protein molecules.

3. Targets (genes) enrichment analysis

(a) Alcohol-modulated genes protein-protein interactions network was analysed by the STRING database and their molecular pathways were analysed by the KEGG pathways. Further, pathways associated with hepatotoxicity and its complications are sorted manually and a datasheet was prepared.

(b) Phytocompounds regulated set of genes proteinprotein interactions network was analyzed by the STRING database and their molecular pathways were analyzed by the KEGG pathways. Further, pathways associated with hepatotoxicity and its complications are sorted manually and a datasheet was prepared.

4. Network construction

Based on the pathways analysis, the network between (i) Alcohol, its targets, and pathways; (ii) phytocompounds-proteins-pathways were constructed by the
Cytoscape ver. 3.6.1. The edge count topological parameter was applied for assessing the degree of interaction among the multiple nodes to identify the maximum interacting protein molecules and pathways.

\section{Docking studies}

Phytocompounds 2D and 3D structures were downloaded from the PubChem and converted 2D into 3D using Marvin sketch software. The energy minimization step for compounds was carried out using MMFF94 forcefield by open babel to minimize the clashes during docking simulation. $\mathrm{X}$-ray crystallographic structure of protein molecules was retrieved from the RCSB PDB. Docking of protein-ligand was carried out by PyRx 0.8v software and their interactions were visualized by Discovery Studio Visualizer 2019.

\section{Statistical analysis}

The data were expressed in mean \pm SEM/SD and assessed via "one-way ANOVA" followed by "Dunnet's multiple comparison" executing through GraphPad Prism. $p<0.05$ were considered statistically significant.

\section{Results}

\section{Antioxidant activity}

\section{DPPH free radical scavenging activity}

Scavenging effect of DPPH plotted in a graph with Absorbance vs Concentration of Ylang Ylang oil and compared with Ascorbic acid (Standard antioxidant agent). The DPPH scavenging response was found to be dose-dependent. All the concentrations of Ylang Ylang oil exhibited DPPH scavenging property. The concentration of 400 and $800 \mu \mathrm{g} /$ $\mathrm{ml}$ showed the highest percentage inhibition i.e., $72.61 \%$ and $77.71 \%$ respectively. On the other hand, standard drug Ascorbic Acid exhibited a percentage inhibition of $85.99 \%$ and $92.99 \%$. The $\mathrm{IC}_{50}$ value of YYEO was identified to be $221.08 \mu \mathrm{g} / \mathrm{ml}$ while Std molecule Ascorbic acid exhibited an $\mathrm{IC}_{50}$ value of $84.82 \mu \mathrm{g} / \mathrm{ml}$. The DPPH free radical scavenging activity of YYEO is shown in Fig. 1 a.

\section{NO free radical scavenging activity}

Nitrous Oxide (NO) radical scavenging assay performed for YYEO and Ascorbic acid at 50-800 $\mu \mathrm{g} / \mathrm{ml}$ concentration and $\%$ free radical scavenging was plotted against concentrations of Ylang Ylang oil v/s absorbance. At the concentration $800 \mu \mathrm{g} / \mathrm{ml}$, YYEO showed percentage inhibition of $75.14 \%$ whereas Standard Drug Ascorbic acid showed $97.84 \%$ inhibition. YYEO exhibited an $\mathrm{IC}_{50}$ value 

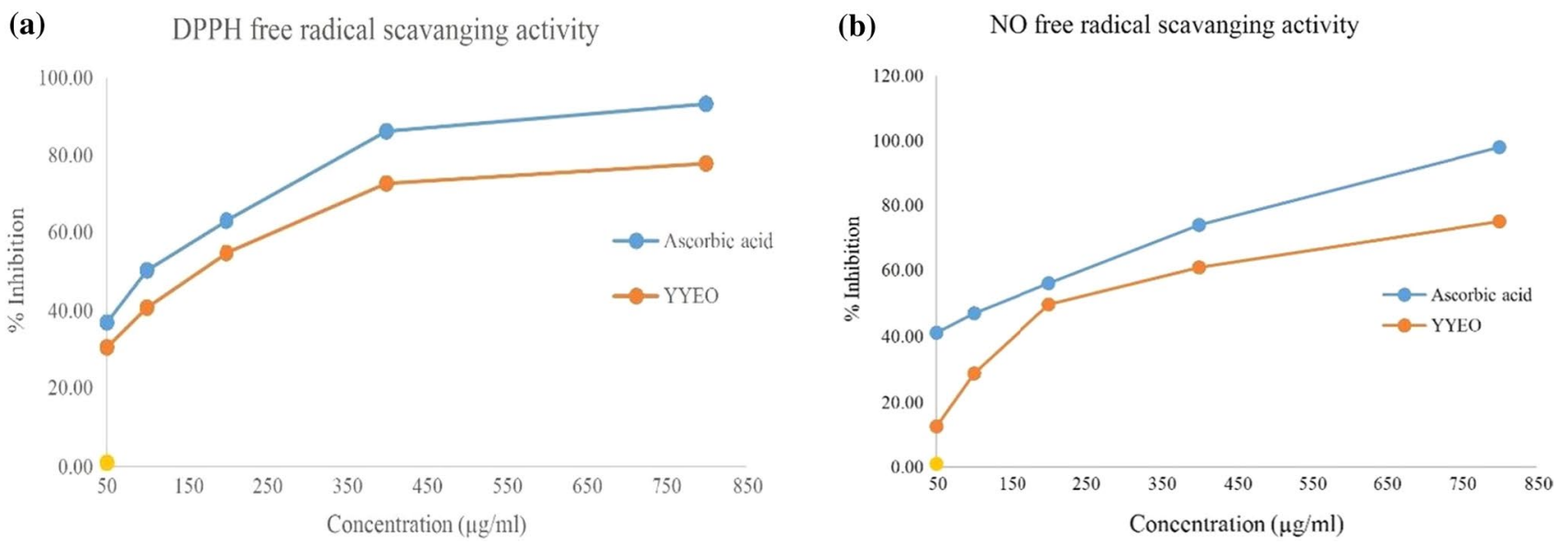

Fig. 1 Effect of YYEO on a DPPH free radical scavenging activity $\mathbf{b}$ NO free radical scavenging activity

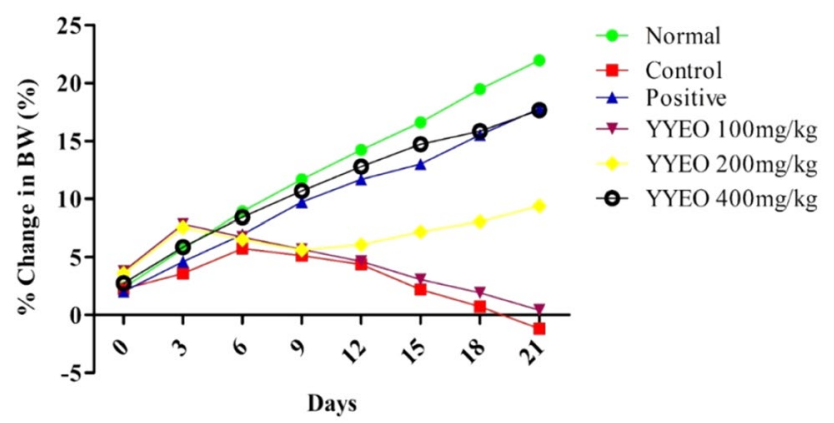

Fig. 2 Effect of YYEO on body weight. All values are expressed as Mean \pm SEM where $\mathrm{n}=6 .{ }^{*} p<0.05, * * p<0.01$ and $* * * p<0.001$

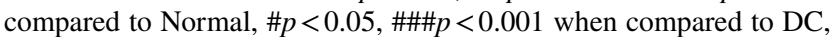
$\Delta \Delta \Delta p<0.001$ when compared to PC, @@ $p<0.01$, @@@ $p<0.001$ compared to Low Dose, ${ }^{\wedge} p<0.05,{ }^{\wedge \wedge \wedge} p<0.001$ compared Mid Dose

of $371.83 \mu \mathrm{g} / \mathrm{ml}$ whereas Standard molecule Ascorbic acid showed $133.30 \mu \mathrm{g} / \mathrm{ml}$.The NO free radical scavenging activity of YYEO is shown in Fig. $1 b$.

\section{Effect of YYLE on body weight}

The effect of YYLE on body weight in normal, Alcoholinduced liver toxicity and YYEO treated rats were examined and \% change in body weight is given in Supplementary Table 1 and Fig. 2. In normal treated rats, a gradual increase in the bodyweight is observed from day 0 to 30 i.e., $2.36 \%$ on 0 th day and $21.95 \%(p<0.001)$ on day 30 th. However, in the alcohol-treated group, an increase in body weight on 0th (2.23\%), 3rd day (3.59\%), and 6th day (5.73\%) was observed and from day $9(5.11 \%)$ to day $30(-1.19 \%)$ $(p<0.001)$ gradual decline in body weight was observed. Further, the positive control group (Silymarin) reversed the alcohol-induced decreased body weight that showed initially a $2 \%$ increase in body weight 0 th day and $17.79 \%(p<0.001)$ on the 30th day. Similarly, YYEO 200 and $400 \mathrm{mg} / \mathrm{kg}$ exhibited gradual increase in the body weight from day $0(3.58 \%$, $2.72 \%)$ to day $30(9.37 \%, 17.65 \%)$.

\section{Serum biochemical and enzyme estimations}

The overall data is represented in Supplementary Table 2 and Fig. 3.

\section{Total protein}

Disease control $(115.55 \pm 4.23)$, Positive Control $(70.38 \pm 4.02), 100 \mathrm{mg} / \mathrm{kg}$ group $(97.24 \pm 1.51)$ and $200 \mathrm{mg} /$ $\mathrm{kg}(82.13 \pm 1.94)$ displayed significant $(p<0.001, p<0.05$, $p<0.001$ and $p<0.001$ ) enhancement in TP level compared to Normal $(67.28 \pm 1.59)$. In treated groups such as Positive Control, 100, 200, and $400 \mathrm{mg} / \mathrm{kg}(70.36 \pm 3.21)$, DC displayed significant $(p<0.001)$ increase in TP level. 100 and $200 \mathrm{mg} / \mathrm{kg}$ exhibited remarkable $(p<0.001, p<0.001)$ increase in TP level compared to PC. $200 \mathrm{mg} / \mathrm{kg}$ and $400 \mathrm{mg} /$ $\mathrm{kg}$ of YYEO displayed remarkable $(p<0.001)$ reduction in TP level compared to $100 \mathrm{mg} / \mathrm{kg}$ (Fig. 3a).

\section{Total cholesterol}

Disease control $(3.22 \pm 0.04), 100 \mathrm{mg} / \mathrm{kg}(2.86 \pm 0.03)$, $200 \mathrm{mg} / \mathrm{kg}(1.84 \pm 0.03)$ and $400 \mathrm{mg} / \mathrm{kg}(1.49 \pm 0.02)$ exhibited remarkable $(p<0.001, p<0.001$ and $p<0.05)$ increased TC level compared to Normal $(1.44 \pm 0.03)$. DC group exhibited remarkable $(p<0.001)$ increase $(3.22 \pm 0.04)$ in TC level compared to Positive Control $(1.49 \pm 0.01)$, $100 \mathrm{mg} / \mathrm{kg}(2.86 \pm 0.03), 200 \mathrm{mg} / \mathrm{kg}(1.84 \pm 0.03)$ and $400 \mathrm{mg} / \mathrm{kg}(1.49 \pm 0.02)$. In contrast to Positive Control, $100 \mathrm{mg} / \mathrm{kg}$ and $200 \mathrm{mg} / \mathrm{kg}$ displayed remarkable $(p<0.001)$ TC level enhancement. In accordance with $100 \mathrm{mg} / \mathrm{kg}, 200$ 


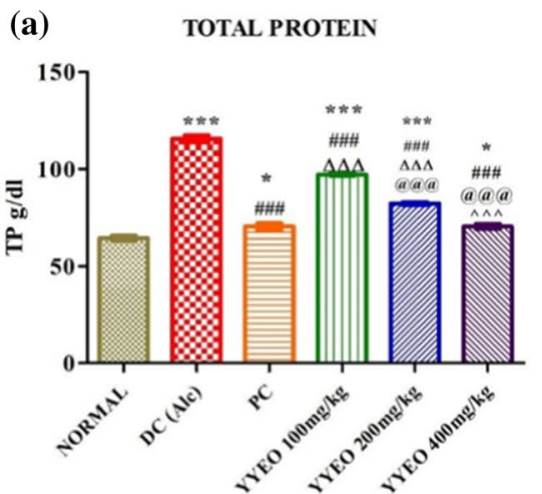

(b)

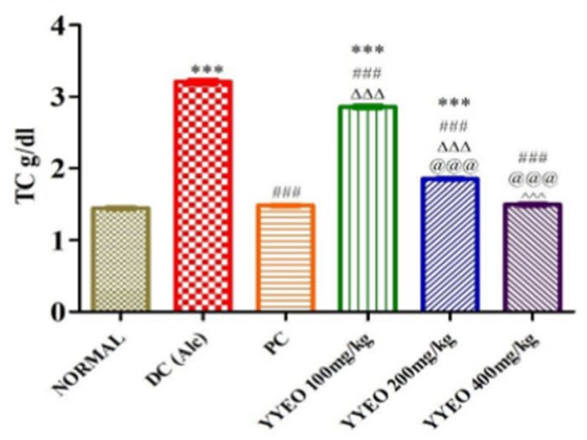

(d)

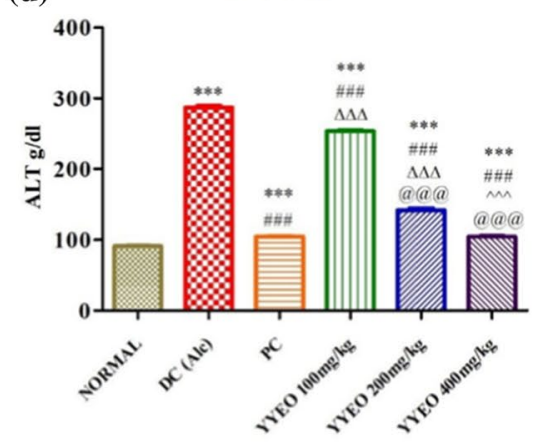

(e)

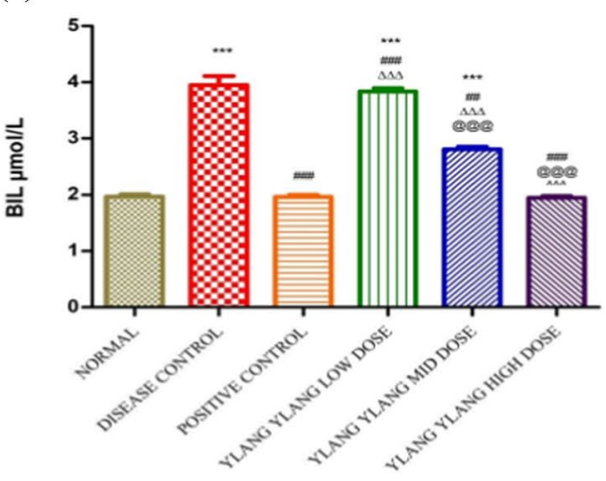

(c)

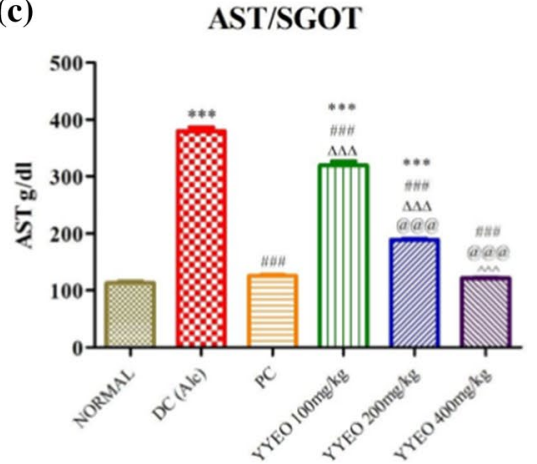

(f)

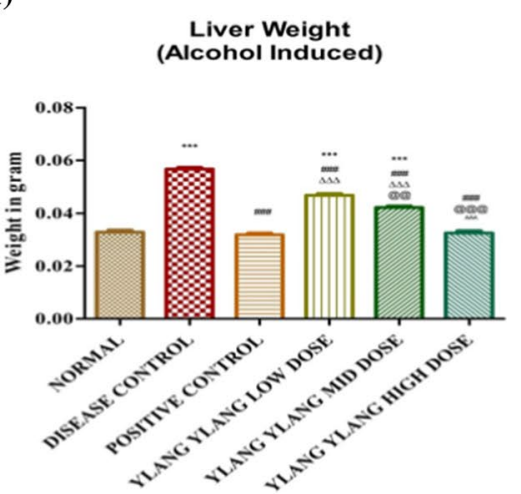

Fig. 3 Effect of YYEO on a total protein $\mathbf{b}$ total cholesterol $\mathbf{c}$ AST d ALT e Bilirubin $\mathbf{f}$ liver weight. All values are expressed as Mean \pm SEM where $\mathrm{n}=6 . * p<0.05, * * p<0.01$ and $* * * p<0.001$

and $400 \mathrm{mg} / \mathrm{kg}$ resulted in significant $(p<0.001)$ reduction in TC level (Fig. 3b).

\section{Aspartate aminotransferase}

Disease control $(379.86 \pm 16.30), \quad 100 \mathrm{mg} / \mathrm{kg}$ $(319.29 \pm 17.57)$ and $200 \mathrm{mg} / \mathrm{kg}(188.87 \pm 7.29)$ exhibited remarkable $(p<0.001)$ raise in AST level compared to Normal $(112.11 \pm 6.30)$. In accordance with treated groups (Positive Control (125.81 \pm 3.42$), 100 \mathrm{mg} / \mathrm{kg}, 200 \mathrm{mg} / \mathrm{kg}$ and $400 \mathrm{mg} / \mathrm{kg}(121.87 \pm 1.84)$, Disease control group exhibited remarkable $(p<0.001)$ raise in AST level. Compared to Positive Control, $100 \mathrm{mg} / \mathrm{kg}$ and $200 \mathrm{mg} / \mathrm{kg}$ group and $400 \mathrm{mg} / \mathrm{kg}$ was exhibited remarkable $(p<0.001)$ elevation in AST level. 200 and $400 \mathrm{mg} / \mathrm{kg}$ group exhibited remarkable $(p<0.001)$ decline in AST level compared to $100 \mathrm{mg} /$ $\mathrm{kg}$ group. Remarkable $(p<0.001)$ decline in AST level was seen in $400 \mathrm{mg} / \mathrm{kg}$, when compared to $200 \mathrm{mg} / \mathrm{kg}$ (Fig. 3c).

\section{Alanine aminotransferase}

Disease control $(286.85 \pm 6.533)$, Positive Control $(104.34 \pm 2.945), 100 \mathrm{mg} / \mathrm{kg}(253.93 \pm 3.145), 200 \mathrm{mg} / \mathrm{kg}$ compared to Normal, \#p<0.05, \#\#\#p<0.001 when compared to DC, $\Delta \Delta \Delta p<0.001$ when compared to PC, @@ $p<0.01$, @@ @ $p<0.001$ compared to Low Dose, ${ }^{\wedge} p<0.05,{ }^{\wedge \wedge} p p<0.001$ compared Mid Dose

$(141.76 \pm 7.291)$ and $400 \mathrm{mg} / \mathrm{kg}(104.61 \pm 2.911)$ resulted remarkable $(\mathrm{p}<0.001)$ rise in ALT level on compared to Normal $(89.64 \pm 3.124)$. Compared to treated groups (Positive Control, 100, 200 and $400 \mathrm{mg} / \mathrm{kg}$ ), DC group showed significant $(p<0.001)$ increase in ALT level. 100 and $200 \mathrm{mg} / \mathrm{kg}$ groups were showing remarkable rise in ALT level compared to Positive Control. 200 and $400 \mathrm{mg} /$ $\mathrm{kg}$ were showing remarkable $(p<0.001)$ decline in ALT level compared to $100 \mathrm{mg} / \mathrm{kg}$. A significant $(p<0.001)$ decrease in AST level was seen in $400 \mathrm{mg} / \mathrm{kg}$, when compared to $200 \mathrm{mg} / \mathrm{kg}$ treated group (Fig. 3d).

\section{Bilirubin}

Disease control $(3.95 \pm 0.40), 100 \mathrm{mg} / \mathrm{kg}(3.84 \pm 0.15)$, $200 \mathrm{mg} / \mathrm{kg}(2.81 \pm 0.11)$ and $400 \mathrm{mg} / \mathrm{kg}(1.95 \pm 0.08)$ showed remarkable $(\mathrm{p}<0.001, \mathrm{p}<0.001$ and $\mathrm{p}<0.05)$ rise in bilirubin compared to Normal $(1.96 \pm 0.09)$. While, Positive Control (1.96 \pm 0.09$), 100,200$, and $400 \mathrm{mg} / \mathrm{kg}$ exhibited remarkable $(p<0.001)$ decline in bilirubin. In contrast to Positive Control, 100 and $200 \mathrm{mg} / \mathrm{kg}$ displayed remarkable $(p<0.001)$ bilirubin level enhancement. In 
accordance with 100,200 , and $400 \mathrm{mg} / \mathrm{kg}$ resulted in remarkable $(p<0.001)$ decline in bilirubin (Fig. 3e).

\section{In-vivo antioxidant activity}

The overall data is represented in Supplementary Table 3 and Figs. 4 and 5.

\section{Catalase}

There is no remarkable difference shown among the control, DC and other treated groups. DC $(41.67 \pm 15.259)$, PositiveControl $(54.49 \pm 12.275), 100 \mathrm{mg} / \mathrm{kg}(38.46 \pm 7.402)$, $200 \mathrm{mg} / \mathrm{kg}(44.87 \pm 9.065)$ and $400 \mathrm{mg} / \mathrm{kg}(51.28 \pm 9.065)$ groups were exhibited decline in CAT level compared to Normal $(54.49 \pm 8.276)$. In contrast to treated groups (Positive Control 100, 200, and $400 \mathrm{mg} / \mathrm{kg}$ ), DC exhibited decline in CAT level (Fig. 4a).

\section{Lipid peroxidation}

DC $(49.68 \pm 3.205)$ exhibited remarkable $(p<0.001)$ rise in LPO level on comparing to Normal Group $(20.83 \pm 6.137)$. Treated groups such as Positive Control $(25.64 \pm 5.234)$, $100 \mathrm{mg} / \mathrm{kg}(35.26 \pm 3.701), 200 \mathrm{mg} / \mathrm{kg}(30.45 \pm 6.137)$ and $400 \mathrm{mg} / \mathrm{kg}(20.83 \pm 6.137)$ exhibited remarkable $(p<0.001$, $p<0.05, p<0.001, p<0.001)$ decline in LPO level compared to Disease control. On comparing with Positive Control group, $100 \mathrm{mg} / \mathrm{kg}$ and $200 \mathrm{mg} / \mathrm{kg}$ groups exhibited decline in LPO level. However, $400 \mathrm{mg} / \mathrm{kg}$ group exhibited remarkable $(p<0.01, p<0.05)$ decline in LPO level compared to $100 \mathrm{mg} / \mathrm{kg}$ and $200 \mathrm{mg} / \mathrm{kg}$ group respectively (Fig. 4b).

\section{Glutathione}

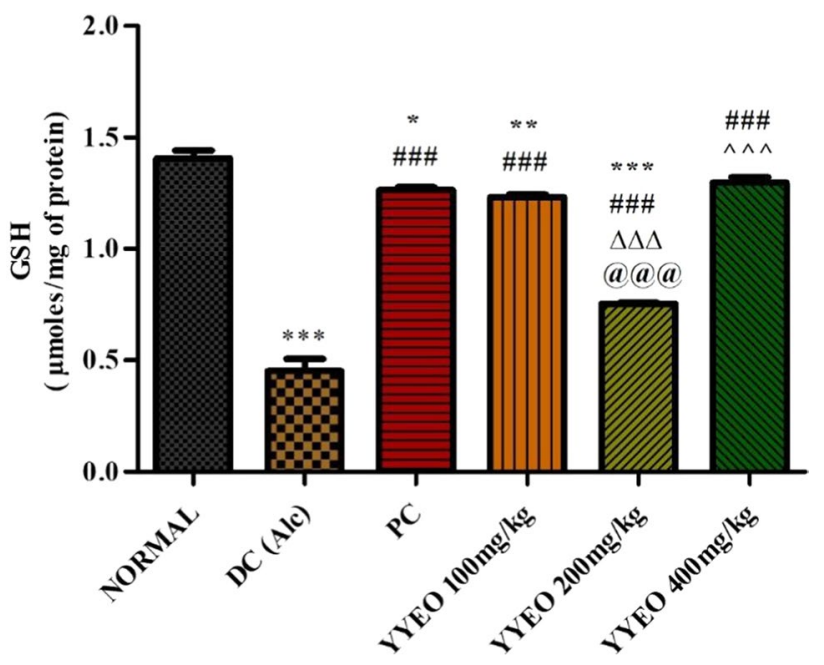

Fig. 5 Effect of YYEO on GSH. All values are expressed as Mean \pm SEM where $\mathrm{n}=6 .{ }^{*} p<0.05$, ** $p<0.01$ and $* * * p<0.001$ compare to Normal, $\# p<0.05$, \#\#\#p<0.001 when compared to DC, $\Delta \Delta \Delta p<0.001$ when compared to PC, @@ $p<0.01$, @ @ @ $p<0.001$ compared to Low Dose, ${ }^{\wedge} p<0.05,{ }^{\wedge \wedge \wedge} p<0.001$ compared Mid Dose

\section{Superoxide dismutase}

There is no remarkable difference shown between the control, DC, and all the treated groups. DC $(70.03 \pm 109.065)$ exhibited a decline in SOD level compared to the Normal Group (243.86 \pm 49.503$)$. Treated groups such as Positive Control $(99.71 \pm 165.819), 200 \mathrm{mg} / \mathrm{kg}(144.50 \pm 121.465)$ and $400 \mathrm{mg} / \mathrm{kg}(141.55 \pm 339.445)$ exhibited decline in SOD level compared to DC. 200, and $400 \mathrm{mg} / \mathrm{kg}$ group exhibited decline in SOD level compared to $100 \mathrm{mg} / \mathrm{kg}$ group (Fig. 4c).

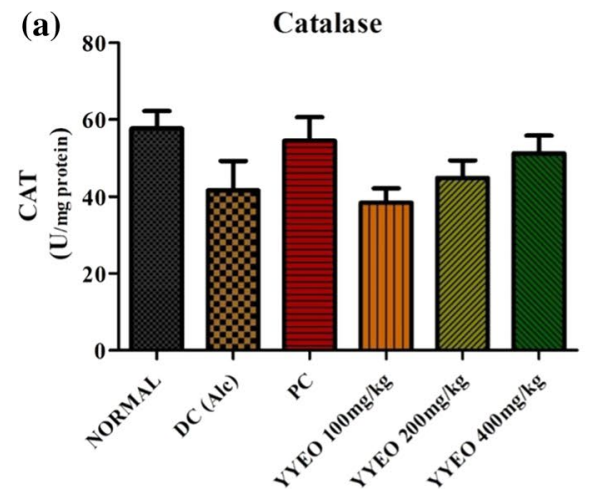

Fig. 4 Effect of YYEO on a CAT b LPO c SOD. All values are expressed as Mean \pm SEM where $\mathrm{n}=6$. ${ }^{*} p<0.05, * * p<0.01$ and

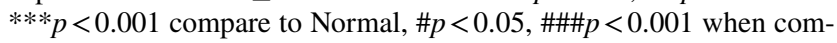
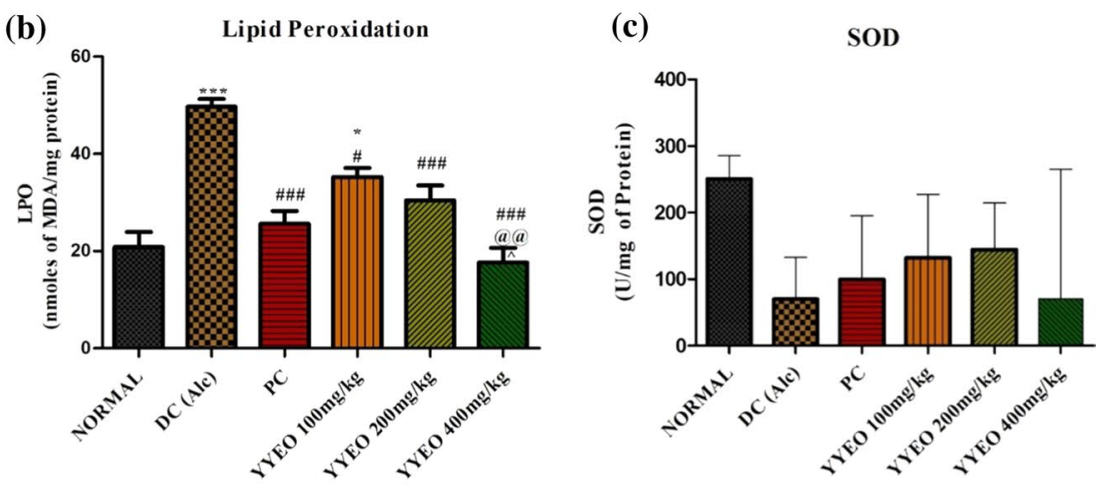

pared to DC, $\Delta \Delta \Delta p<0.001$ when compared to PC, @ @ $p<0.01$, @@@ $p<0.001$ compared to Low Dose, ${ }^{\wedge} p<0.05,{ }^{\wedge \wedge \wedge} p<0.001$ compared Mid Dose 


\section{Glutathione}

DC (0.45 \pm 0.104$)$, Positive Control (1.26 \pm 0.027$), 100 \mathrm{mg} /$ $\mathrm{kg}(1.23 \pm 0.025)$, and $200 \mathrm{mg} / \mathrm{kg}(0.75 \pm 0.010)$ exhibited remarkable $(p<0.001, p<0.05, p<0.01, p<0.001)$ decline in GSH level compared to Normal Group (1.41 \pm 0.073$)$. Treated groups viz., Positive Control, 100, 200, and $400 \mathrm{mg} /$ $\mathrm{kg}(1.30 \pm 0.046)$ exhibited remarkable $(p<0.001)$ rise in GSH level compared to DC. When compared to PC, $200 \mathrm{mg} /$ $\mathrm{kg}$ exhibited remarkable $(p<0.001)$ reduction in GSH level. $200 \mathrm{mg} / \mathrm{kg}$ exhibited remarkable $(p<0.001)$ reduction in GSH level compared to $100 \mathrm{mg} / \mathrm{kg}$ group. $400 \mathrm{mg} / \mathrm{kg}$ exhibited remarkable $(p<0.001)$ elevation in GSH level compared to $200 \mathrm{mg} / \mathrm{kg}$ (Fig. 5).

\section{Effect on liver weight}

Disease control $(0.0569 \pm 0.00163), 100 \mathrm{mg} / \mathrm{kg}$ $(0.0467 \pm 0.00163)$ and $200 \mathrm{mg} / \mathrm{kg}(0.0422 \pm 0.00147)$ exhibited remarkable $(p<0.001, p<0.001$ and $p<0.05)$ increase in liver weight compared to Normal $(0.0328 \pm 0.00194)$. Likewise, DC group also saw a significant $(p<0.001)$ increase in liver weight compared to Positive Control (0.0318 \pm 0.00160$), 100,200$ and $400 \mathrm{mg} / \mathrm{kg}$ $(0.0325 \pm 0.00207)$. In contrast to Positive Control, both 100 and $200 \mathrm{mg} / \mathrm{kg}$ displayed remarkable $(p<0.001)$ liver weight enhancement. In accordance with $100 \mathrm{mg} / \mathrm{kg}, 200 \mathrm{mg} / \mathrm{kg}$ and $400 \mathrm{mg} / \mathrm{kg}$ resulted in significant $(p<0.001, p<0.01)$ reduction in Liver weight (Supplementary Table 4, Fig. 3f).

\section{Histopathology}

Normal group rat's histopathology examination displayed a normal histology at $40 \times$ magnification while Alcohol treated rats group showed a-focal collection of lymphocytes around hepatocytes within the lobule, b-spotty necrosis, c-lymphocytic infiltration around portal tract, and micro vesicular steatosis. Silymarin group showed a spotty (minute) necrosis in hepatocytes. While rats treated with YYEO $(100-400 \mathrm{mg} / \mathrm{kg})$ showed a reduction in the lymphocytic infiltration around the portal tract and showed mild necrosis. The histopathology results have been summarised in Fig. 6.

\section{In silico studies}

\section{Retrieval of bioactives from YYEO and collection of their information}

About 65 bioactive phytocompounds were shortlisted fromYYEO and their druggability w.r.t. Lipinski rule of five was summarized in Supplementary Table 5.

\section{Targets related to Alcohol and Phytocompounds}

Alcohol: Based on the literature, Alcohol was found to target 63 protein molecules to cause hepatotoxicity.

Phytocompounds: Based on target prediction by Swiss Target Prediction 65 phytocompounds from YYEO were predicted to modulate 71 protein molecules.
Fig. 6 Histopathology of the Liver for Alcohol Induced Animal. a Normal group, b Disease Control, c Standard, d YYEO Low Dose, e YYEO Mid Dose and $\mathbf{f}$ YYEO High Dose
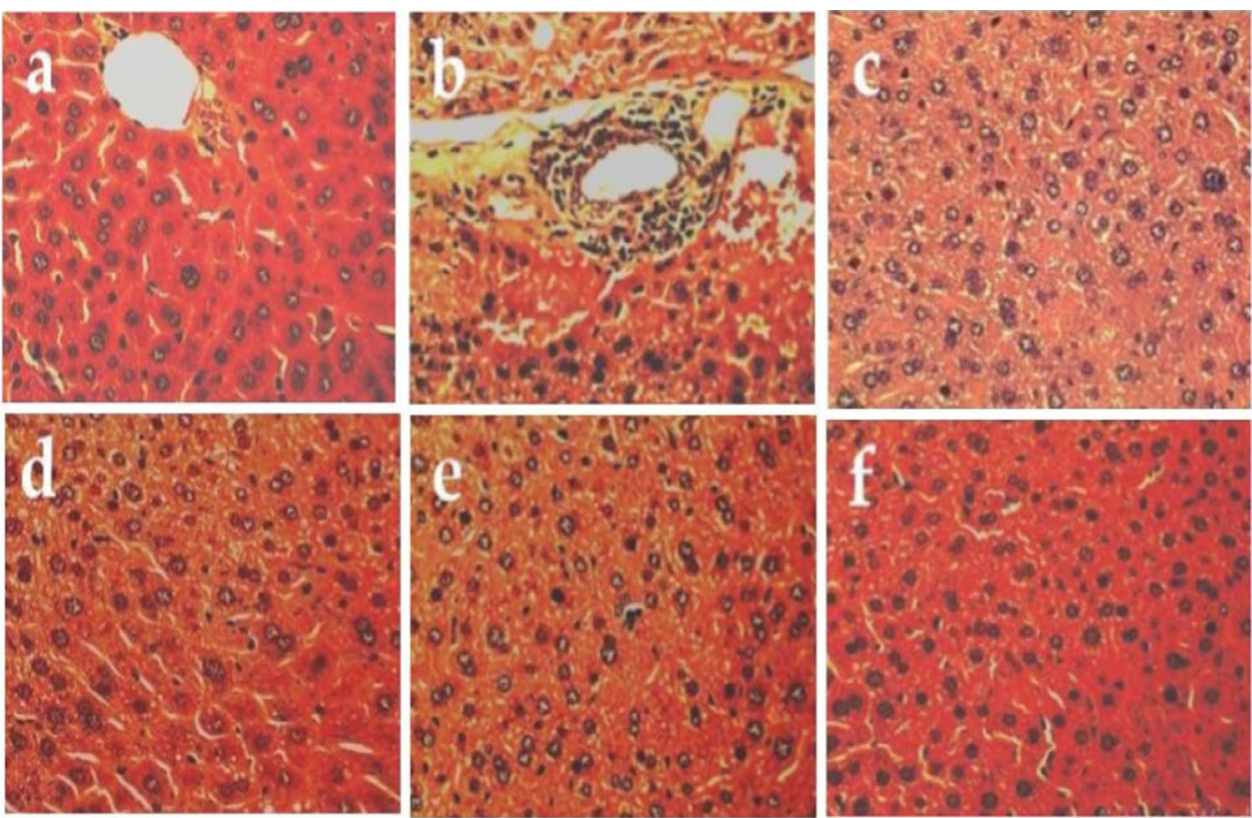


\section{Targets (genes) enrichment and network analysis}

Alcohol The enrichment analysis of 63 protein molecules targeted by Alcohol was found to modulate 182 molecular pathways. Among 182 pathways, 51 were associated/related to hepatotoxicity (Supplementary Table 6). NAFLD, Tolllike receptor, Adipocytokine, TNF, Sphingolipid, FoxO, AMPK, Relaxin, MAPK, NF-kappa B, HIF-1, Fc epsilon RI, IL-17, VEGF, T cell receptor, NOD-like receptor, mTOR, PI3K-Akt signaling pathway, etc. were found to score the least FDR value and significantly modulated by Alcohol. Figure 7 represents the alcohol-target-pathway network.
Phytocompounds The enrichment analysis of 71 protein molecules targeted by 63 phytocompounds were found to modulate 169 molecular pathways. Among 169 pathways, 62 were associated/related to hepatotoxicity (Supplementary Table 7). HIF-1 signaling pathway, Hepatitis B related mechanisms, EGFR tyrosine kinase inhibitor resistance, PI3K-Akt, Calcium, Estrogen, Relaxin, IL-17, NF-kappa B, TNF, MAPK signaling pathways, etc. were found to score the least FDR. Figure 8 represents the phytocompoundsprotein targets andpathways network.

\section{Docking studies}

Based on the target prediction, therapeutic targets, and literature on YYEO constituents effect protein target "Aldose

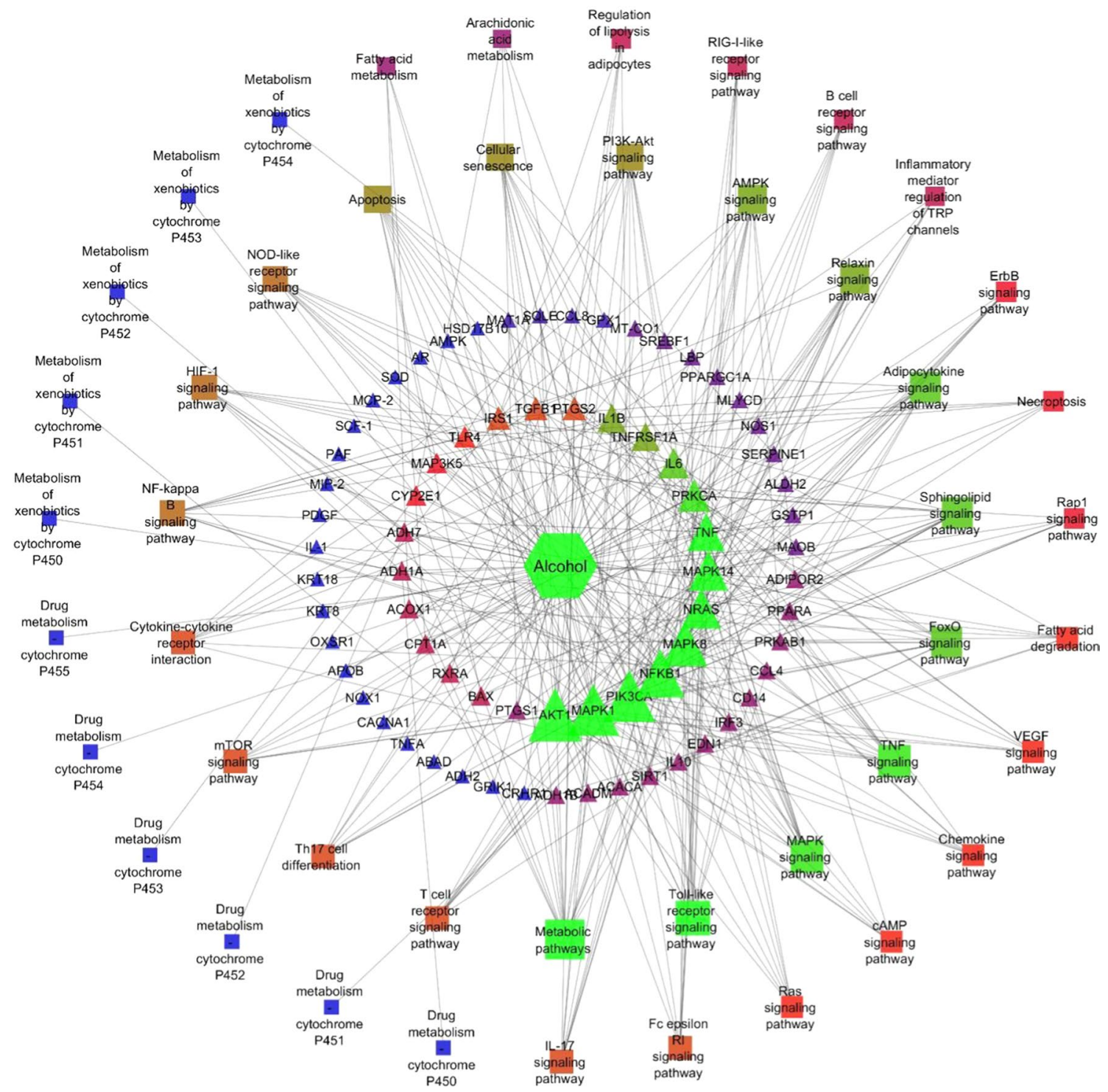

Fig. 7 Network representation of Alcohol, regulated genes, and their molecular pathways 


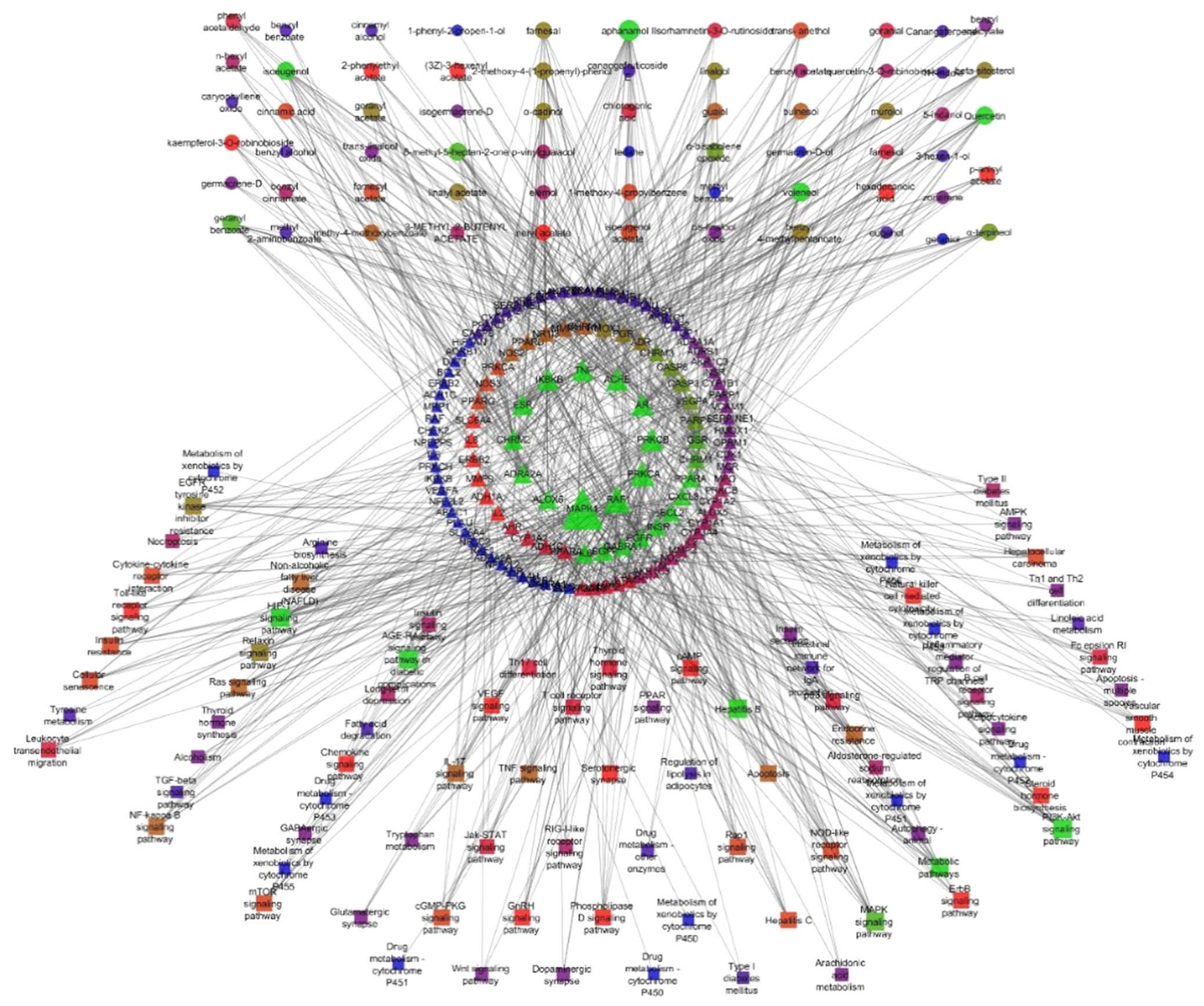

Fig. 8 Network representation of YYEO phytocompounds, probable protein molecules, and their molecular pathways

Reductase (AR)" was chosen to identify YYEO constituent's interactions with AR. Among 63 compounds, 7 compounds viz., Benzyl cinnamate, Canangaterpene 1, Cinnamic acid, Kaempferol, Quercetin, and Isoeugenol were predicted to target AR. Sulindac sulfone, a known standard aldose reductase inhibitor was also docked with aldose reductase enzyme for comparison purpose. Among them, Canangaterpene 1 scored the lowest BE of $-10 \mathrm{kcal} / \mathrm{mol}$ via forming $1 \mathrm{HBI}$ i.e. His110, and 6 NHBI i.e., Tyr209, Trp20 (2), Cys298, Val47, Ile260. Canangaterpene 1 formed 7 interactions with active site residues. Interestingly, all 7 compounds formed interactions with active site residues (supplementary Table 8). Figure 9 represents the interaction of phytocompounds withAR.

\section{Discussion}

The present study was carried to explore the hepatoprotective and antioxidant efficacy of ylang ylang essential oil in drug-induced hepatotoxicity (Alcohol-induced hepatotoxicity) in Wistar rats. This study mainly includes three stages (1) in vitro, (2) in vivo followed by biochemical estimation, (3) In silico studies to probe the molecular mechanisms of YYEO.

Liver cells seem to take part in an assortment of protein metabolic functions, and alcohol causes effective hepatic harm at the doses used (Kenneth et al. 1992). The development of ROS cause oxidative stress and hepatocellular injury have been involved in alcoholic liver disease. It has been reported that Kupffer cells are the significant wellsprings of ROS during severe alcohol intake, and these initiated for 


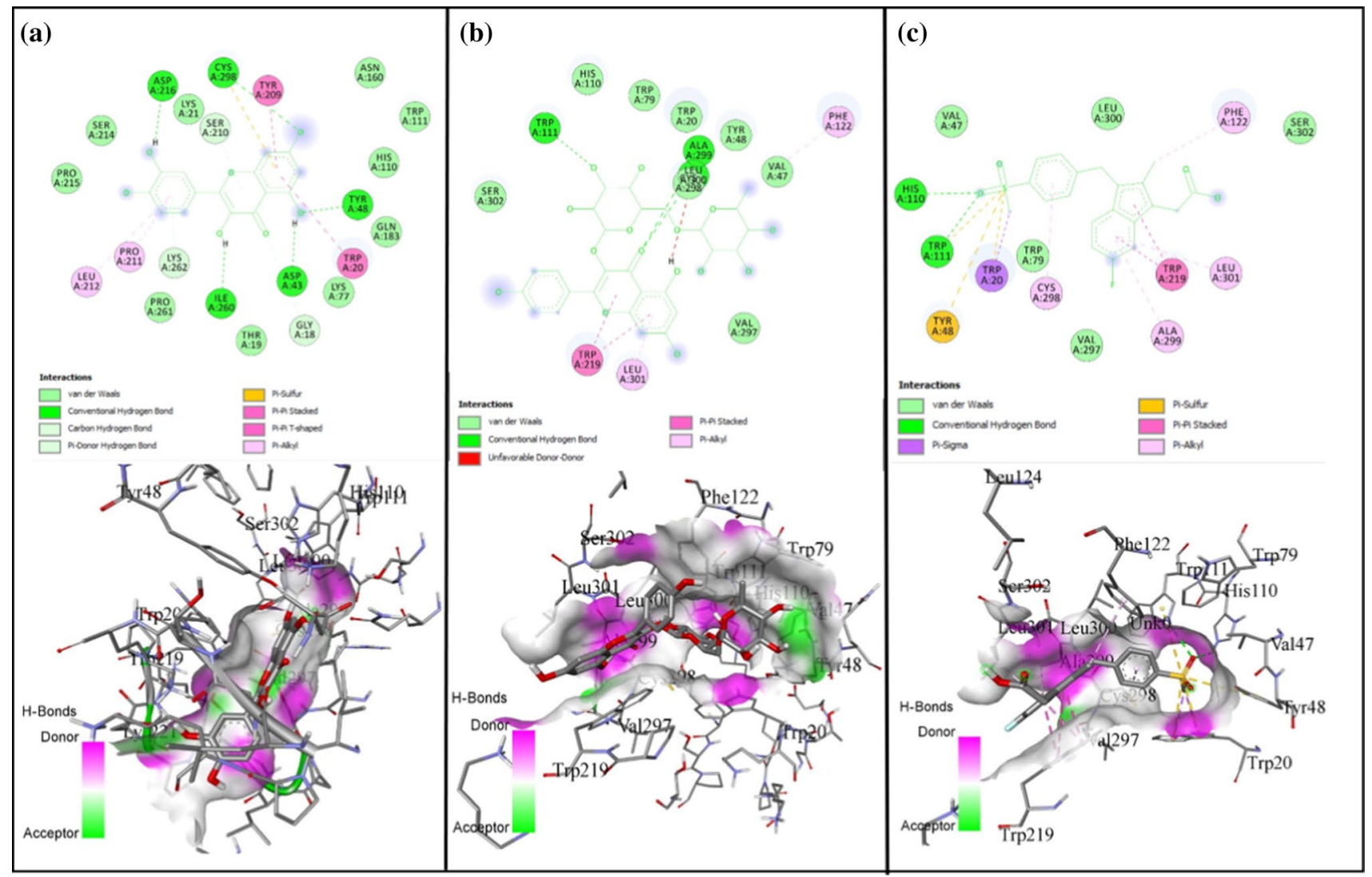

Fig. 9 2D and 3D representation of interaction of aldose reductase with a Quercetin, b Kaempferol c Sulindac sulfone. *Sulindac sulfone is a standard aldose reductase inhibitor molecule

improved formations of pro-inflammatory influences (Bautista et al. 2001). Moreover, alcohol-induced liver injury has been related to the expanded measure of lipid peroxidation (Nanjiet al. 2003). As a result, it's possible that the raised levels of marker chemicals including ALP, ALT, AST, and bilirubin resulted in the "loss of membrane structure and integrity" due to LPO process. In fact, in our investigation, YYEO supplementation Alcohol model was conceivably viable in blunting lipid peroxidation via reducing MDA level, recommending that the concentrate potentially has antioxidant prevention agent property to reduce membrane lipid peroxidation, which could be because of high level triterpenoids, and other moieties as "flavonoids, saponins glycosides, triterpenoids, and tannins" (Patel et al. 2011).

In the current study examination further we uncovered that long alcohol exposure, diminished ROS potency, viz., SOD and CAT, which in accordance with supposition recommended before by Balasubramaniyan et al. (2003) that decline in the action of antioxidants viz., "GSH, CAT, and SOD subsequent alcohol contact might be because of the harmful impacts of ROS or then again could be because of an immediate impact of acetaldehyde, produces from oxidation of alcohol (Das et al. 2005). In the current study, YYEO administration could reestablish the activity of these antioxidant prevention agents and could decrease the occurrence of free radicals and hepatic harm which may be due to the presence of bioactive moeties in YYEO mainly terpenoids and sterols that are known to possess antioxidant capacity (Gautam et al. 2007, Singh et al. 2008).

From our investigation, more prominent histopathological impacts were observed as cell changes that were noticed more in the Disease Control treated rats with a longer span of exposure in the liver. The DC group exhibited chronic damage and slight construct, and necrosis, and also this was found similar in the $100 \mathrm{mg} / \mathrm{kg}$ group with additional mild hemorrhage. However, PC exhibited reversible mechanism to NC via little degeneration and normal histology. PC and $400 \mathrm{mg} / \mathrm{kg}$ group exhibited similar effects on histology with slight degeneration followed by congestion.

Further, the study is extended to explore the molecular mechanisms behind the hepatoprotective action of YYEO. First, protein targets modulated by Alcohol were retrieved from literature and it was found that alcohol targeted 63 protein molecules. Enrichment analysis of 63 protein targets of alcohol were found to modulate 51 pathways associated/ related to the hepatotoxicity viz., Non-alcoholic fatty liver disease (NAFLD), Toll-like receptor, Adipocytokine, TNF, 
Sphingolipid, FoxO, AMPK, Relaxin, MAPK, NF-kappa B, HIF-1, Fc epsilon RI, IL-17, VEGF, T cell receptor, NODlike receptor, mTOR, PI3K-Akt signaling pathway, etc.

On the other hand, 63 bioactive molecules from YYEO were found to target 71 protein molecules. Enrichment analysis of 71 targets was found to modulate 62 pathways associated/related to the hepatotoxicity viz., HIF-1 signaling pathway, Hepatitis B related mechanisms, EGFR tyrosine kinase inhibitor resistance, PI3K-Akt, Calcium, Estrogen, Relaxin, IL-17, NF-kappa B, TNF, MAPK signaling pathways, etc. Majorly, among these pathways, Hepatitis B related mechanisms, EGFR tyrosine kinase inhibitor resistance, PI3K- Akt, HIF-1, Calcium, Estrogen, Relaxin, IL-17, NF-kappa B, MAPK signaling pathways were found to share with Alcohol and Paracetamol induced hepatotoxicity. These findings corroborate the in vitro and in vivo findings and provide support for the hepatoprotective action of YYEO. Further, based on the target prediction, therapeutic targets, and literature on YYEO constituents to target a protein molecule "Aldose Reductase (AR)" was chosen to identify YYEO constituent's intramolecular interactions with AR. Among 63 compounds, 7 compounds viz., Benzyl cinnamate, Canangaterpene 1, Cinnamic acid, Kaempferol, Quercetin, Sulindac sulfone, and Isoeugenol were predicted to target AR. Among them, Canangaterpene 1 scored the lowest $\mathrm{BE}$ via forming $1 \mathrm{HBI}$ and $6 \mathrm{NHBI}$. Canangaterpene 1 formed 7 interactions with active site residues. Interestingly, all 7 compounds formed interactions with active site residues, which supports their major AR inhibitory effect.

\section{Conclusion}

Our study suggested a significant protective effect of YYEO extract against Alcohol-induced hepatotoxicity and reports $400 \mathrm{mg} / \mathrm{kg}$ as a recommended dose in adult Wistar rats which brings serum and antioxidant biomarkers to normal level. Hence, YYEO could be one of the best sources of natural hepatoprotective agents. YYEO is rich in antioxidant compounds, which support the antioxidant and hepatoprotective properties Alcohol-induced model. Although, YYEO constituents are found to blunt molecular pathways dysregulated by Alcohol. Further research work on the clarification of its gene expression and individual compound action that may exhibit potent hepatoprotective property in rodents is needed to be carried out.

Supplementary Information The online version contains supplementary material available at https://doi.org/10.1007/s13596-022-00630-w.

Acknowledgements The authors thank to the Principal of KLE College of Pharmacy, Belagavi for providing necessary facilities to carry out the research work.
Author's contribution Siddarth Tubachi conducted the experiments, wrote and drafted the manuscript. Dr. V.P. Rasal designed the study and supervised the work. Sanjay Ugare assisted in the design of the study. NA Khatib helped in critical review and analysis of the manuscript and reviewed the final manuscript. Prachi Sanjeev Ojha and Vishal Patil assisted in data analysis and interpretation, writing of manuscript, and revision.

Funding None.

\section{Declarations}

Ethical statement The study protocol was reviewed and approved by the Institutional Animal Ethics Committee, KLE College of Pharmacy, Belagavi, and Resolution No. KLECOP/CPCSEA- Reg. No. 221/Po/ Re/S/2000/CPCSEA, Res. No. 29-03/09/2020. The animal experiments were carried out in accordance with the CPCSEA guidelines.

Conflict of interest Siddarth Sunil Tubachi has no conflict of interest. V. P. Rasal has no conflict of interest. Sanjay R. Ugare has no conflict of interest. Nayeem A. Khatib has no conflict of interest. Prachi Sanjeev Ojha has no conflict of interest. Vishal S. Patil has no conflict of interest.

Open Access This article is licensed under a Creative Commons Attribution 4.0 International License, which permits use, sharing, adaptation, distribution and reproduction in any medium or format, as long as you give appropriate credit to the original author(s) and the source, provide a link to the Creative Commons licence, and indicate if changes were made. The images or other third party material in this article are included in the article's Creative Commons licence, unless indicated otherwise in a credit line to the material. If material is not included in the article's Creative Commons licence and your intended use is not permitted by statutory regulation or exceeds the permitted use, you will need to obtain permission directly from the copyright holder. To view a copy of this licence, visit http://creativecommons.org/licenses/by/4.0/.

\section{References}

Ali M, Ramachandran R, Rafiullah MRM et al (2004) Prevention of carbon tetrachloride-induced hepatotoxicity by the ethanol extract of Capparismoonii fruits in rats. Pharm Biol 42:286-288

Amit R, Bhoumik D, Ram KS, Jaya D (2014) Medicinal plants used in liver protection - a review. Pharma Biosci J

Baba SA, Malik SA (2014) Evaluation of antioxidant and antibacterial activity of methanolic extracts of Gentianakurrooroyle. Saudi J Biol Sci 21:4938

Balasubramaniyan V, Sailaja JK, Nalini N (2003) Role of leptin on alcohol-induced oxidative stress in Swiss mice. Pharmacol Res 47:211-216

Bautista AP (2001) Free radicals, chemokines and cell injury in HIV-1 and SIV infections and alcoholic hepatitis. Free Radic Biol Med 31:1527-1532

Boora F, Chirisa E, Mukanganyama S (2014) Evaluation of nitrite radical scavenging properties of selected zimbabwean plant extracts and their phytoconstituents. J Food Process 2014:1-7

Burdock GA, Carabin IG (2008) Safety assessment of Ylang Ylang (Cananga spp.) as a food ingredient. Food Chem Toxicol $46(2): 433-445$

Claiborne A (1985) Catalase activity. In: Greenwald RA (ed) CRC handbook of methods for oxygen radical research. CRC Press, Boca Raton, pp 283-284 
Das D, Mukherjee S, Mukherjee M et al (2005) Aqueous extract of black tea (Camellia sinensis) prevents chronic ethanol toxicity. Curr Sci 88:952-961

Ellman G (1959) Tissue sulfhydryl groups. Arch Biochem Biophys 82(1):70-77

Gautam SP, Ganjiwale RO, Yeole PG (2007) Free radical scavenging properties of aqueous extract of Tecomella undulata leaves. Indian J Nat Prod 23:33-37

Kenneth LM, Howard FM, Brain BH, et al (1992) Melmon and Morrelli's clinical pharmacology. In: Basic principles in therapeutics, vol 233. McGraw-Hill, London. p 799

McCuskey RS (1991) In vivo microscopy of the effects of ethanol on the liver in liver pathology and alcohol 563-570. Humana Press, Totowa, N.J.

Mohan H (2002) Textbook of pathology, 4th edn. Jaypee brother's medical publisher, New Delhi

Nanji AA, Jokelainen K, Tipoe GL et al (2003) Curcumin prevents alcohol-induced liver disease in rats by inhibiting the expression of NFKB-dependent genes. Am J Physiol Gastrointest Liver Physiol 284:G321-G327

Ohkawa H, Ohishi N, Yagi K (1979) Assay for lipid peroxides in animal tissues by thiobarbituric acid reaction. Anal Biochem 95(2):351-358
Patel KN, Gupta G, Goyal M, et al (2011) Assessment of hepatoprotective effect of Tecomella undulata (Sm.) Seem., Bignoniaceae, on paracetamol-induced hepatotoxicity in rats. Braz J Pharm 21:133-138

Sharma U, Kumar S (2009) Hepatoprotective activity of some indigenous plants. Int J Pharm Tech Resh 4:1330-1334

Singh P, Khandelwal P, Hara N et al (2008) Radermachol and naphthoquinone derivatives from Tecomella undulata: complete $1 \mathrm{H}$ and 13C NMR assignments of radermachol with the aid of computational 13C shift prediction. Indian J Chem 47B:1865-1870

Sun M, Zigman S (1978) An improved spectrophotometric assay for superoxide dismutase based on epinephrine autoxidation. Anal Biochem 90(1):81-89

Terrence MN (2011) Alcoholic liver disease: pathogenesis and current management. Alcohol Res 38(2):147

Publisher's Note Springer Nature remains neutral with regard to jurisdictional claims in published maps and institutional affiliations. 